\title{
RESEARCHPAPER
}

\section{Bioefficacy of wild plant extract for biological control of insect pests of Bt cotton}

\author{
U.B. HOLE, S.M. GANGURDE, N.D. SARODE AND R.W. BHARUD \\ Cotton Improvement Project Mahatma Phule Krishi Vidyapeeth, Rahuri, AHMEDNAGAR (M.S.) INDIA
}

Article Info :Received : 23.08.2014; Revised : 01.09.2015; Accepted : 17.09.2015

Wild plant fruit extract such as hinganbet, Balanites roxburghii, ritthaa/soap nut, Sapindus trifoliatus, shikekaaee, Acacia concinna, Neem, Azadirachta indica, Karanj, Pongamia pinnata and vekhand, Acorus calamus L. were evaluated to screen their efficiency for the control of sucking pests of Bt cotton during Kharif 2009 to 2012 at Cotton Improvement Project, Mahatma Phule Krishi Vidyapeeth, Rahuri. All the organic pesticide treatments were superior over untreated control. Among the evaluated organic pesticides the treatment with 5 per cent hingan bet extract @ 2 litre per hectare was observed to be effective in reducing pest population in which aphids, jassids, thrips and whiteflies of 22.68, 8.16, 14.53 and 10.97 per three leaves, respectively, were recorded with the seed cotton yield of 20.77 quintal per hectare. However, this treatment was statistically at par with 5 per cent ritthaa extract @ 2 litre per hectare. The treatment with 5 per cent ritthaa extract recorded aphids, jassids, thrips and whiteflies of $23.16,9.87,15.34$ and 12.65 per three leaves, respectively, with the seed cotton yield of 20.09 quintal per hectare. The treatment with 5 per cent NSE @ 2 litre per hectare recorded 28.96, 12.61, 17.71 and 15.18 aphids, jassids, thrips and whiteflies per three leaves, respectively, with the seed cotton yield of 12.31 quintal per hectare. The phytotoxicity studies on leaf injury on tips and leaf surface, wilting, vein necrosis, epinasty and hyponasty showed that there was no phytotoxic effect of the evaluated pesticides on cotton crop at the evaluated doses. The counts on natural enemies in the treatments with hinganbet and ritthaa extract were more or less similar to those recorded in untreated control. This clearly indicated that there was no adverse effects on natural enemies due to spraying of hinganbet and ritthhaa extract at evaluated doses.

Key words : Bt cotton, Kharif, Sucking pests, Organic pesticide, Hingan bet, Balanites roxburghii, Soap nut, Sapindus trifoliatus, Phytotoxicity

How to cite this paper : Hole, U.B., Gangurde, S.M., Sarode, N.D. and Bharud, R.W. (2015). Bioefficacy of wild plant extract for biological control of insect pests of Bt cotton. Asian J. Bio. Sci., 10 (2) : 167-170. 